\title{
A tribute to Paul Hendrich: engaging anthropology
}

\author{
By Alpa Shah (Goldsmiths, University of London)
}

This issue, Engaging Anthropology, is dedicated to the memory of Paul Hendrich, who died on Wednesday, January 16, 2008. We are deeply grieved, devastated, to lose you, Paul.

\section{Anthropology and action}

Since its earliest days, anthropology has been controversially interested in applied practice. Malinowski (1929), for instance, called for a 'practical anthropology'. In Britain, the relationship between anthropology and applied practice was critically marked by anthropology's involvement in colonialism (see Asad 1973, Bennett 1996). In the aftermath of the independence revolutions, the ethics of anthropology's engagement with colonialism was questioned. These critiques were bolstered by parallel ones of the use of anthropology in war activities, as spies and for military training. As a result of this colonial and war guilt many anthropologists started to retreat from more practical roles.

In the 1970s, however, a new era of collaboration between anthropology and applied practice emerged with an interest within the discipline towards Marxism and political economy, which set the stage for close engagement between anthropologists and the organisations and institutions charged with implementing capitalist development policy. Many anthropologists engaged in development with a strong sense of political purpose to bring anthropological knowledge to address issues of problems of poverty, exploitation and global inequality. More and more anthropologists were employed in development. This emerging development anthropology, however, became increasingly criticised on several grounds. Some authors called for a postdevelopment era, as they saw development as one more discourse for the domination of nonwestern societies by western powers. They represented anthropologists in development as practicing a form of neo-colonial domination (Escobar 1995). And there was also the argument that development anthropology was becoming too adjusted to the bureaucratic demands of development agencies at the expense of intellectual rigour and critical self-consciousness. As James Ferguson (1997:152) argues, the resultant

antipathy of mainstream anthropology for development, as well as the sharp separation of an applied development anthropology from a theoretical academic sort, may be taken as signs not of anthropology's critical distance from development but of its uncomfortable intimacy with it.

Today these debates on the relationship between anthropology and development are played out in other practical spheres where the discipline matters - in human rights 
administration and in activism and advocacy, for instance. The tension between intellectual rigour as cultural critique and the mainstreaming of solutions for effective practical action is one that faces all of us as politically engaged anthropologists. Should we 'get our hands dirty' and engage in the 'militant anthropology' that Nancy Scheper-Hughes (1995) calls for, and what are the dangers in doing so? Or should we follow the advice of Iris Jean-Klein and Annelise Riles (2005) and prioritise ethnographic rigour and holism over the immediate needs of advocacy and action? Do our arguments change if we change the context of practical action? Engaging in development or in political advocacy or in human rights administration is often justified on moral grounds. But how do we feel about the recent debates around counterinsurgency operations employing anthropologists in military operations (see Price 2002, 2007)?

Clearly these are highly contentious issues and my purpose here is not to elaborate or debate them. Here, I want to draw attention to one angle of the debate that is perhaps taken for granted but is rarely commented on in our published writing, and that fundamentally questions the divide between a strictly theoretical anthropology and an anthropology that has applied relevance. This is the consideration of teaching as a form of engaging anthropology.

\section{Teaching as a form of engaging anthropology}

Teaching is a crucial domain in which 'anthropology matters', and whether we like it or not, we 'engage anthropology' through the social relations of the teaching process. Our dialectical relations with our students, the conversations and debates we develop in class, the readings that we discuss and analyse, in turn affect the way in which we all think and act in the world. The majority of anthropology students go on to work in non-academic roles-for example, as development consultants, journalists, and lawyers - and how they critically engage in the world over the course of their degrees does fundamentally matter in their roles outside the academy. Not only can the relationships that develop through teaching change the way in which we might act in the world, but they can also transform the discipline of anthropology itself. So no matter how carefully we might want to maintain a divide between mainstream anthropology and applied anthropology, our role as academics and our role as activists, this divide shatters when we start to reflect on and analyse the processes that take shape in and out of our classrooms.

From 2004-2006, I had the pleasure of co-convening an MA in Applied Anthropology and Community and Youth Work at Goldsmiths, University of London. This is a programme that is run jointly between the Anthropology Department and the Community and Youth Work section of the Department of Professional and Community Education. Set up in 1992, it is the first British postgraduate MA in Applied Anthropology. Although I do not doubt that teaching is a form of engaging and rethinking anthropology more generally, teaching on this particular MA programme crucially drove home this point. On the MA in Applied Anthropology and Community and Youth Work, most of the students are experienced youth workers, working with underprivileged, marginalised youth in the UK. The MA, and in particular the theoretical and methodological tools of anthropology, provides a space for them to critically reflect on and reengage their everyday struggles as youth workers as well as contribute to anthropological theory, and this is nowhere more evident than in their dissertations. 
This edition of Anthropology Matters brings together articles which originated as some of the most thought-provoking MA Applied Anthropology and Community and Youth Work dissertations of 2005-2006, to show the ways in which the theoretical and methodological tools from anthropology can enable students (who are also youth workers in this case) to take a step back and critically reflect and reengage in the world in which they live and work.

\section{Themes: youth, marginalisation, inequalities and policies}

Saffron Burley's fantastic contribution analyses the growing trend among young people in urban areas in the UK to own fighting dog breeds such as bull terriers, and the resultant 'moral panic' that this has caused among dominant groups. In the West London neighbourhood popularly known as Notting Hill, low-income groups live in hostels, estates and housing association accommodation in close proximity to those with abundant economic and social capital. Having an already established relationship with some of the young people from low-income groups of West Indian, North African and White European backgrounds, because of her role as youth worker in the area, Burley employed participant observation over the course of her MA by taking a young Pit Bull Terrier called 'Biscuit' out for walks in the area, in order to understand these young people better.

The result is an insightful ethnographic account which explores the subtle potentials that exist in the union of the young person and the dog. Burley shows the importance of the self-esteem and respect that owning and fighting these dogs provide in a context where the youth are otherwise marginalised and vulnerable because of their income level and social class. Commenting on the poetic irony of the modern fight dog and its devotion to its master, she speaks of the central role of the project of domination involved in keeping a dangerous animal: "Perhaps the dog can in this sense be seen as having transcended beyond existence as a "solution", "symbol" or even "companion", but can in fact be admired here as a simple "work of art", a contemporary rebuke to our colonial history.' Burley's work not only contributes to our understanding of inequality, marginalisation and animal-human relations, but concludes with some lessons for community and youth workers-rather than seeing the dogs as 'problems', as external to the young person, the dog needs to be drawn into the centre of understandings of the dilemmas and tensions faced by youth.

The question of youth marginalisation is also addressed by the next four articles, which in related yet differing ways all focus on UK Government approaches to participation, citizenship and youth. While Rachel Ashcroft and Helen Clark are concerned with the youth participation agendas of New Labour policy in Britain, Beccy Blow points out the ways in which the language of empowerment and participation disguises institutional forms of discrimination that continue to exclude people with learning difficulties from participating as equal citizens, and Rayen Salgado-Pottier analyses the moral panic post $9 / 11$ that has increasingly constructed young British Pakistani and Bangladeshi men as the most recent 'folk devils'.

I will not dwell on each at length here, but would like instead to draw attention to a few emerging themes and the fruitful deployment of perspectives from the anthropology of development into youth work in the UK. In the line of Ferguson's (1990) thinking on a World Bank funded development project in Lesotho, Ashcroft shows the ways in which the discourse of participation acts as a wider form of control, 
cohesion and consumption that serves to enhance New Labour's own legitimacy. As youth are classified as anti-social, New Labour is able to construct a project of social cohesion in which community involvement, volunteering and participation are central. Aschcroft argues that by reframing the idea of youth participation in a depoliticised way, as active citizens of a passive notion of citizenship, young people are reconstructed as passive consumers - an argument that enhances the power and legitimacy of the Government. Similarly, Clark analyses Government policy in the form of the Respect Action Plan of 2006 and the Youth Matters Green Paper of 2005 to show the way in which the Government's approach to citizenship is leading to the creation of good subjects rather than good citizens. She draws on examples taken from her own experience of government-initiated 'youth forums' and her observations of the 'rules of thumb' used in a government-funded charity working with homeless young people.

Blow and Salgado-Pottier also analyse discourses of participation, this time in the shape that they have taken in UK Government policies directed at adults with learning difficulties (the 'community care' approach) and in relation to young British men of Pakistani and Bangladeshi backgrounds (the 'community cohesion' approach) respectively. Using illustrative examples from her own experience, Blow unpacks the complex ethical considerations of adopting participatory-or apparently participatory-work practices in relation to people with learning difficulties. She argues that the current use of this approach may reinforce an existing lack of power among people with learning difficulties, and that the critique of participation and empowerment that has emerged within the anthropology of development is highly relevant in this field too. Salgado-Pottier draws us into a close examination of how young Bangladeshi and Pakistani men in the UK are defined in the media, imagined in public discourse, and labeled in government policy. She agues that the group in question should be considered to be the modern equivalent of 'folk devils', that is, the imagined 'opposite' of exemplary citizens. Though they are marginalised in many ways - caught in society's structures of inequality - they are repeatedly blamed for an apparently constant breakdown of moral order.

All the papers are in some form interested in the lessons from and for anthropological theory and analysis in its engagement with applied action. The articles focus on youth, encourage youth workers to be critically aware of the policy discourses with which they operate, the structural inequalities which they veil, and promote a more reflexive praxis of working with youth in order to create spaces of critical thinking between them.

\section{A tribute to Paul Hendrich: engaging anthropology}

The issue of engaging anthropology in action both methodologically and theoretically is nowhere more evident than in Paul Hendrich's inspiring and innovative project on 'Charting a new course for Deptford Town Hall'. Hendrich examines his own institutional context at Goldsmiths College and the debates surrounding the institutional responsibilities for controversial artifacts of the past, in this case the history of the racism of the British slave trade that is embedded in Deptford's former Town Hall, an ornately sculptured building with a golden (and perhaps slave) ship above it, that is now under the ownership of the College. Hendrich is concerned about the contradiction that while race and racism are a major part of the work of some the best academics at Goldsmiths, and the College has a reputation for turning out 
'cutting edge' individuals, nothing has been done to address the question of the appropriateness of Goldsmiths possessing and occupying this building which in some way embodies a celebration of the slave trade.

In a quest to find what could be done to address this contradiction, the process of engaging anthropology in action takes Hendrich to diverse routes. He considers the debates about reparations, the dangers of doing nothing, and issues of local race relations that should be central concerns to Goldsmiths as a white island in a cosmopolitan sea and where a precarious balance is being struck between Goldsmiths as a radical institution and as a growing commercial concern. The result of this anthropology in action was that Hendrich felt that rather than an apology from Goldsmiths for Deptford's part in slavery, what was needed was a public acknowledgement of its connection. So in June 2007, Hendrich reinhabited the Town Hall with the academic ritual of a conference, entitled 'Repairing the Trauma of History', addressing slavery, resistance, apology and reparation, which he hoped would provoke the beginnings of wider public reaction to engage in a dialectic with the controversial monument that will avoid complacency.

As I was putting the finishing touches to this editorial, Paul Hendrich's wife, Sasha, called with the devastating news that Paul had been run over on his bicycle by a lorry. Paul was 36 years old and had a one year old daughter, Agatha. His death is a deep loss to all of us. Paul was a very special person with some extremely rare qualities. His life was committed to engaging an everyday struggle against racism. He held a passion and belief that anthropology could and should be used for and rethought through this struggle against racism and it is this that guided his engagement with academia. He deeply touched the lives of the staff and students at Goldsmiths by his active commitment to this cause through campaigns (such as the Town Hall Pirates and the Sankofa Reconciliation walk in chains to Deptford Town Hall), talks and conferences that he organised and participated in. Paul's MA dissertation on Deptford Town Hall was also part of his broader commitment to rethinking and reworking issues of racism. He completed his Masters with a distinction, a fact that he was quietly proud of, especially since he was the first person in his family to go to university. And then the Goldsmiths Anthropology Department was particularly fortunate that Paul decided to pursue a $\mathrm{PhD}$ in Anthropology. At the time of his death, Paul was continuing his work as a youth worker and had just set up a refugee health drop-in service in South London, and he was also preparing to sail to Arizona, USA, where he wanted to research the various forms of activism that have taken shape around the undocumented cross-border migration of Mexicans into the US. Paul's enthusiasm, generosity, kindness and inclusiveness drew everyone he met into the broader issues that he was thinking about and working on, and those who were fortunate to know him could appreciate what a great youth worker he was and what a great field researcher he would have been. Paul's research would have continued to make us rethink the theoretical and practical issues of engaging anthropology as praxis, and his death is deeply mourned.

\section{References}

Asad, Talal (ed.). 1973. Anthropology and the Colonial Encounter. New York: Humanity Books.

Bennett, John. 1996. Applied and action anthropology: Ideological and conceptual 
aspects. Current Anthropology 37(1), Supplement: S23-S53.

Escobar, Arturo. 1995. Encountering Development: The Making and Unmaking of the Third World. Princeton: Princeton University Press.

Ferguson, James. 1990. The Anti-Politics Machine: 'Development', Depoliticisation, and Bureaucratic Power in Lesotho. Cambridge: Cambridge University Press.

1997. Anthropology and its evil twin. In International Development and the Social Sciences: Essays on the History and Politics of Knowledge (eds) F. Cooper and R. Packard, 150-175. Berkeley: University of California Press.

Jean-Klein, Iris, and Annelise Riles. 2005. Anthropology and human rights administrations: Expert observation and representation after the fact. PoLAR: Political and Legal Anthropology Review 28(2), 173-202.

Malinowski, Bronislaw. 1929. Practical anthropology. Africa 2, 22-38.

Price, David. 2002. Lessons from Second World War anthropology: Peripheral, persuasive, and ignored contributions. Anthropology Today 18(3), 14-20.

. 2007. Buying a piece of anthropology: Part 1: Human ecology and unwitting anthropological research for the CIA. Anthropology Today 23(3), 8-13.

Scheper-Hughes, Nancy. 1995. The primacy of the ethical: Propositions for a militant anthropology. Current Anthropology 36(3), 409-420.

\section{About the author}

Alpa Shah is a Lecturer in the Department of Anthropology at Goldsmiths, University of London. Her research focuses on addressing the reproduction of inequality and the resultant implications for and experiences of marginalised people. Through fieldwork in the state of Jharkhand in Eastern India, her interests grew from concerns of international development to the possibilities offered by social movements in the form of indigenous activism. She can be contacted at a.shah@gold.ac.uk 